\title{
Al-Qur'an: Linguistics and Culture Involve In Research and Other Fields of Science
}

\author{
By Seno H Putra, Drs., M.Pd., P.hD., Prof \\ Professor of Islamic University of Riau, Pekanbaru, Riau Indonesia
}

\begin{abstract}
Linguistics is the Science that We Study about the Languages whether Specific or Universal Languages, or whether Verbal or non Verbal Skills, and It also encompasses some Branches of Linguistics, such as Phonology, Morphology, Syntax, Semantics, etc., including Culture and other fields of Science and Technology. In short word, No Language, No Activities of Human in the World, No Language, No development of Culture, Science and Technology. Language is the Key of Human Life for all Activities in the World.
\end{abstract}

\section{Key Words: Al-Qur'an: Linguistics, Culture, Science and Technology.}

\section{I.Introduction of Language}

Everybody, whether Candidate Scholars, Scholars, Scientists, or Layman always ask somebody or themselves: When does firstly the language appear in the World, especially in the verbal skill? And probably then they also ask: Why is language learnt by interested people ? How is language related to other fields of science? Many questions arise from their minds.

If we observe the Heavens and the Earth, no one in the World is able to create them except Allah S.W.T., as the creater of whole Mankind and all Species in this Earth. If we hear and listen various languages or dialects used by people in various Regions, Cities, and Countries in the World, it is Miracle for us. Therefore, questions Rise in our mind! Where do they derive from, or Who does create the Languages or dialects exist in the World? These the main problems must be thought over by us as Candidate Scholars or Scholars, Scientists, or others. I am as a Writer, when I read Al-Qur'an in the midnight (Sept,2005), I found that Allah S.W.T., firstly created the various Languages in the World. To convince this can be read in His revelations below.

According to Al-Qur'an (Al-Baqarah/the Cow:Revealed at-AlMadinah):

"Allah S.W.T., taught Adam Prophet all the names, then showed them to the Angels, saying: inform me of the names of these, if you are truthfully."

"They said: Be glorifield! We have no knowledge saving that which Thou hast taught us. Lo! Thou, only Thou, art the Knower, the Wise."

"He said: O Adam! Inform them of their names, and when he had informed them of their names, He said: Did I not tell you that I know the secret of the Heavens and the Earth? And I know that which ye disclose and which ye hide."
The Romans (Revealed at Mecca): And if His signs is the creation of the heavens and the earth, and the difference of your languages and colours.Lo! herein indeed are portents for men of knowledge."

From above revelations of Allah S.W.T., the next revelations also came up to the last Prophet is Muhammad S.W.T., as the first event occurred in him as stated in Al-Qur'an as follows.

The first revelation came to Muhammad S.A.W Prophet (Rasulullah )when he was fourty years old. He was asleep or in a Trance in the Cave "Hira"" when he heard a voice say:"Read!" He said: "I can not read." The voice again said: "Read!" He said: "I can not read." A third time the voice, more terrible, commanded:"Read!" He said: "What can I read? The voice said:

\author{
"Read: In the name of thy Lord Who createth. \\ "Createth man from a clot. \\ "Read: And it is thy Lord the most Bountiful. \\ "Who teacheth by the pen, \\ "Teacheth man that which he knew not."
}

Therefore, based on the God's revelations above as He said to Adam Prophet and Muhammad Prophet, it is clear that various Languages in the World are created by the God. However, we are as human only to develop the Languages used by us depending on situation and condition, social status, geography, and the community where the Languages are. Moreover, as Candidate Scholars or Scholars, Scientist, or others who are interested in a or more Language studies, they are expectedly to be able to find out Language studies in community whether individually, in pairs, groups, or others that can be supported the development of Languages as Regional visions, Cities, Countries.

Language studies can also be considered not only for Teaching and Learning processes in the formal setting, but those can be benefits as Linguistic Contributions, as well as to retain and promote them in the forms of writing to the global world. In other words, still many Languages or dialects with different colours in the World are still not studied yet by us or any Scholars, so that we do not know how the forms, systems, styles, etc., of them, especially in written forms (Seno H.Putra, 2001-2004, and OrasillmiahDiestalis UIR, 2004).

Even though Language is various symbol systems derived from lungs, throut, vocal cords, devices of mouth which can be performed to produce various sounds or phonemes in the combinations of consonants, vowels, diphthongs, and supra-segmental phonemes to perform morphemes/words, sentences, discourses, etc., of human communications. Therefore, verbally, Language is not only to send messages from speaker to listener, however, it is also as devices used in Science and Technology (Seno H.Putra, 2004). 


\section{II.Culture in Linguistics, but Not Linguistics in Culture}

I do apologize to everybody who involves in Linguistic Fields, Cultural fields (Anthropology), and others if I criticize them, such as Prof.Dr.Boas; Prof.Dr.Sapir; Prof.Dr.Chomsky; Prof.Dr.Liemkiat boy; Prof.Dr.Chaika; Prof.Dr.KoencaraNingrat, etc., locally scholars, National Scholars, and International Scholars, but not Language in Culture, Culture in Linguistics. In here, I want to analog (Compare) My Hypotheses with/to other Scholars inside or outsiders'hypotheses that can be presented as follows:
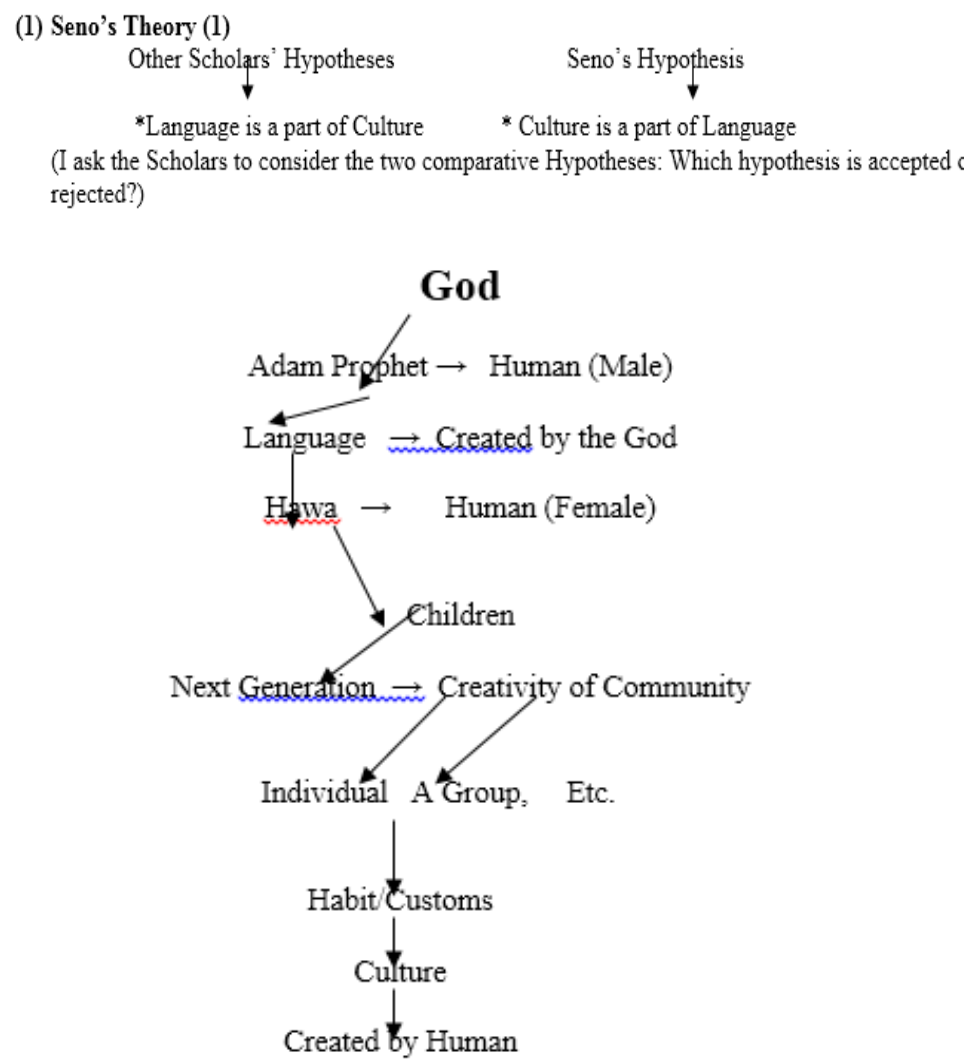

Fig.1. Language is created by the God, and Culture is a part of Language, but not Language is a part of Culture.

Critically, to argue some experts, here I disagree that Language is a part of Culture, but my assumption said that "Culture is a part of Language". Why is it so? In my mind that language firstly appeared in the World rather than Culture, since culture exists because of the creations of human according to social norms, values, and ethics of the community.Other argumentations from my mind, no Culture mentioned by the God in Al-Qur'an, but only "Language" as Revelations above. Therefore, I recommend that "Culture is a part of Language", but not Language is a part of Culture as mentioned by many people. And Also to Prof.Dr.Darwin, I argue his hypothesis that "Human is derived from, or looks like Monkey", but "Human created by the God derived from Land as Adam Creation" (See Al Hijr-28). Moreover, Human created by the God has more potential, innate capacity, Science and Technology, as well as Culture rather than Monkey (animals). In terms of using Language, human develops the Language starting from child until old, where the Language used by them more development than animals, not only in the systems, rules, and pronunciation, but also in the uses of vocabulary (words), etc. (2)

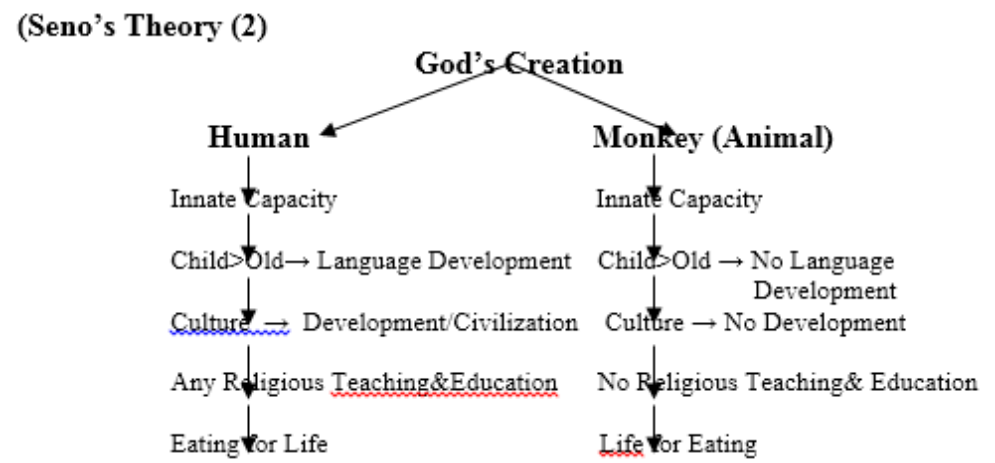

Fig.2.Human Development to use Language and Culture, but Animal no Development on Language,.., and Science

\section{III.Linguistics in Fields of Science}

When we talk over about Linguistics, perhaps we think that only to speak, to write, or only to talk one another. In fact, this is not in such way. Linguistics is also similar to other sciences, even this Language firstly appeared in the World if we compare to other sciences. In other words, no Language whether verbally or non-verbally, no other sciences. So, we are as human must think it over logically, that Linguistics encompasses other branches which can be related to other fields, for examples; Phonology is the science that we study about sounds of Human can also refer to physics and arts; Syntax is the science that We study about arrangements (rules/reconstructions) of the words/morphemes, phrases to perform well sentences into discourse and text can also indicate to Mathematical systems; Morphology is the science that We study about how words formation derived from (stem/root) becomes words classification which have lexical and contextual meanings can also modify Morphological plantation and Economical systems ; Psycholinguistics is the science that we study about Language behavior/mentality individually, in pair, group, etc., that can also refer to the biological processes; Semantics is the science that we study about the meanings of Language involve in words, phrases, sentences, symbols and signals verbally and non-verbally indicate to technological systems; Socio linguistics is the science that we study about Language and dialects used by people in community, in which it tends to Language, Culture, and Sociology; Discourse is the science that we study how we understand the ungrammatical sentences, symbols, and signals through out the Language used by different colors (people); and Pragmatics is the science that we study how sentences or discourses somehow can be interpreted by certain semantics and syntax.

\section{Explanations of Linguistic Science}

\section{What is Phonology?}

Phonology is the science that we study about normal Human speeches (sounds) in verbal skills both specifically and universally. Furthermore, the word of Phonology can be separated into terms: \{phone\} means (sounds $+\operatorname{logy}$ ) is science, so, Phonology is the science of Human sounds in Language. Clearly, see the diagram (1) below. 
Human sounds encompass several devices which can produce Linguistic corpuses, for examples, sounds, phonemes, morphemes/words, phrases, sentences, clauses, and texts. The processes of air stream production go out through the lungs, throut, mouth which also consists of teeth, tongue, palate, larynks, lips, etc., that can be performed to become consonants, vowels, diphthongs, and supra-segmental phonemes of a language. Clearly, see the diagram (2) below.

\section{Diagram (1)}
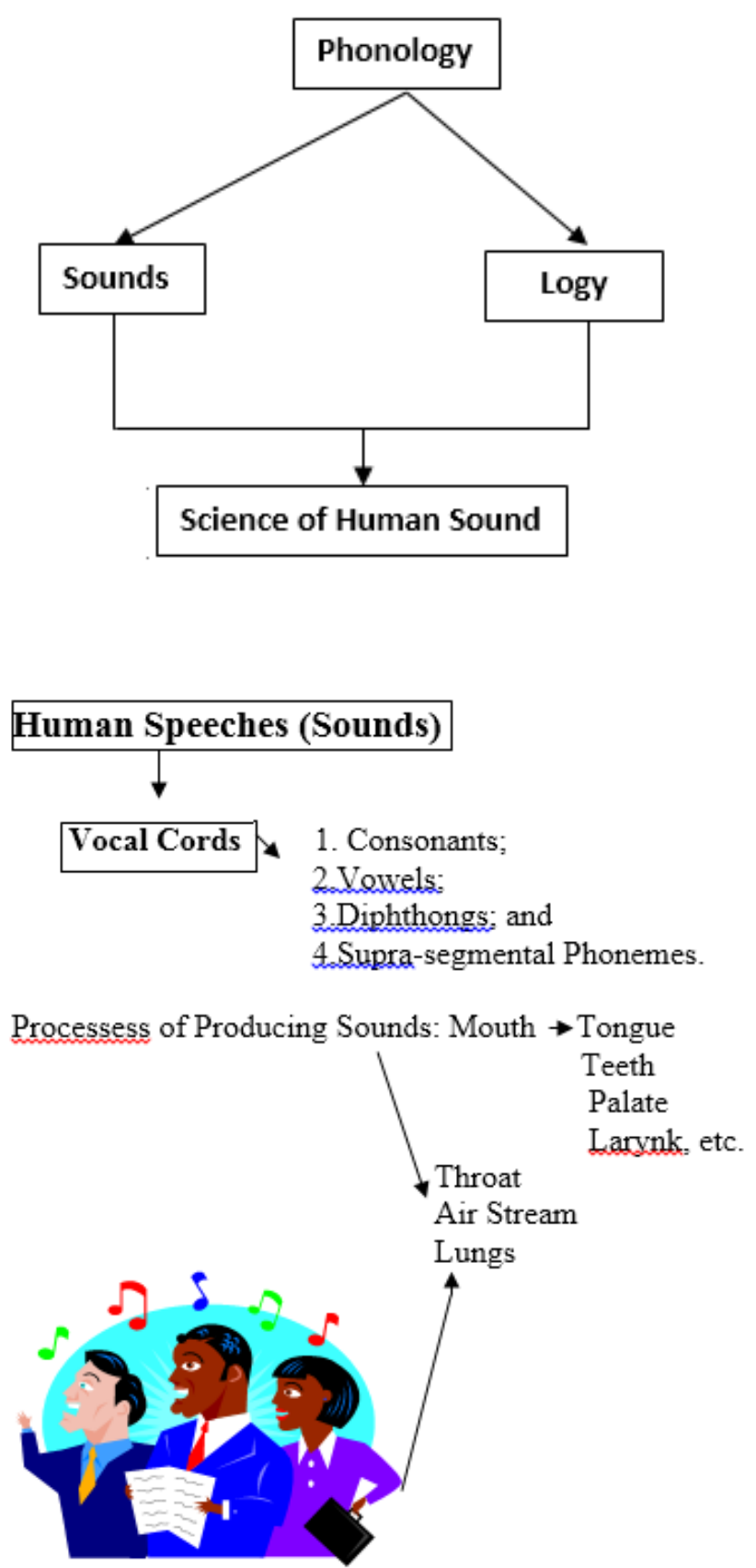

Fig.3.Human Producing Process of Language.

\section{Processes of Producing Sounds become: \\ Phoneme; \\ Morpheme; \\ Words; \\ Sentences; \\ Clauses.etc.}

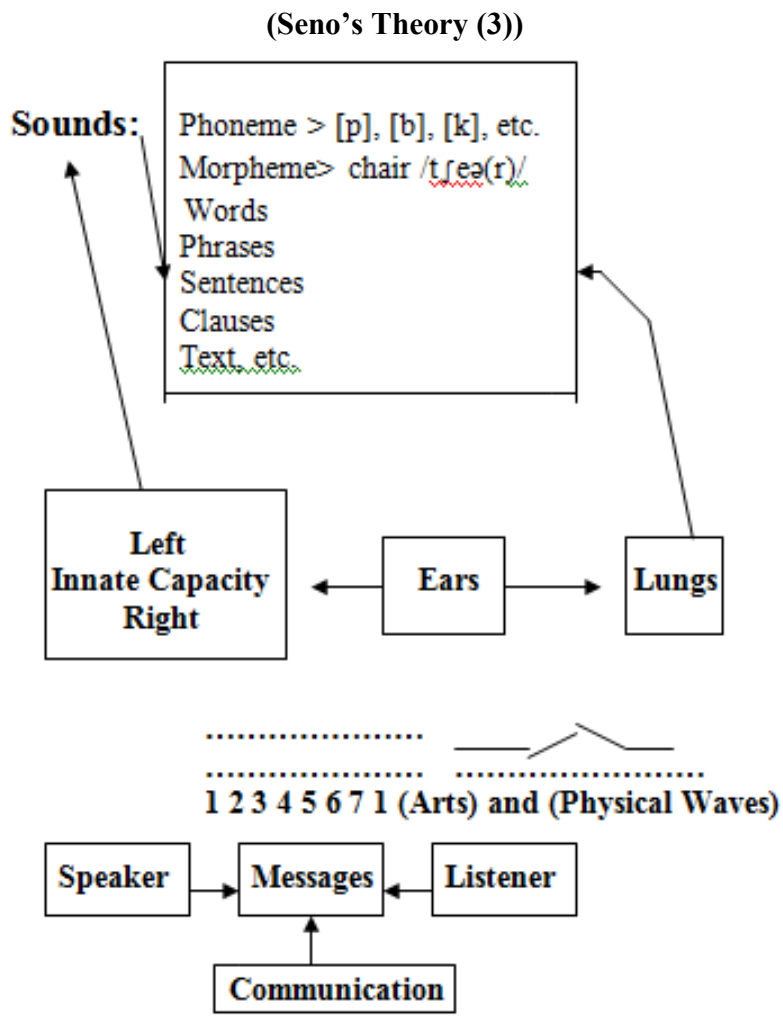

Fig.4 Process of Human Devices to Perform a Language.

Human's Speeches do not look like Robot, but He/She normally has Intonation, Stress, Rythem, etc., in every word and sentence of a Language.

VI.Why is Phonology learned by Language Students?

In Teaching Learning Processes in the classroom, many Phenomena found by us as teachers when the beginners (Students) learn foreign Languages, in here especially English. The problems encountered by us, for examples, (1) Some Consonants of English compared to Indonesian are unfamiliar one another; (2) a few of Vowels of English do not appear in Indonesian; (3) several Diphthongs of English are also different from Indonesian; (4) Supra-segmental phonemes of English are not found in Indonesian; (5) many words of English are sometimes different forms from one another, but sometimes they are the same as abstractness; and so fourth. Therefore, those cases are the main focus 
must be made out by language students and English teachers in Teaching and Learning English as a Foreign Language. To overcome the problems of learning in the classroom are considered not only throughout pronunciation solutions, but also those must be studied and analyzed throughout Phonological Analysis of both forms and abstractness of a Language.

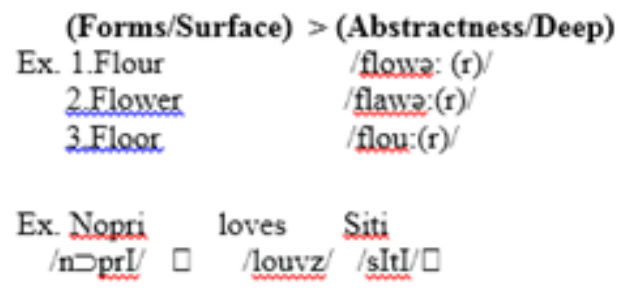

Sounds Change

$\begin{array}{ll}\text { 1. }[\circ] \rightarrow[\supset] & \text { 3. [o] } \rightarrow \text { [ou }]\end{array}$

2. $[$ i] $\rightarrow[\mathrm{I}] \quad$ 4. [s] $\rightarrow[\mathrm{z}]$, etc.

$\left.\begin{array}{c}\begin{array}{c}\text { Ex.good /gud/ } \\ \text { food/fu:d/ } \\ \text { foot /fuit/ }\end{array} \\ {\left[\begin{array}{c}\text { back } \\ \text { relax } \\ \text { vowel } \\ \text { [u] }\end{array}\right]}\end{array}\right]\left[\begin{array}{c}\text { back } \\ \text { tense } \\ \text { vowel } \\ \text { [u:] }\end{array}\right]$

VII.Processes of Language Production

(Seno's Theory (4))

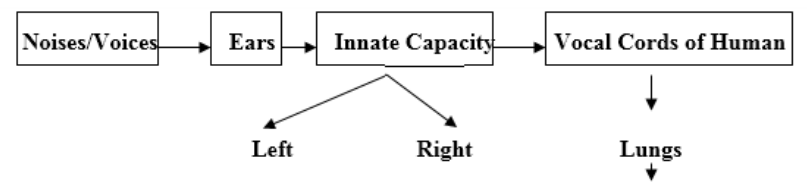

Throut

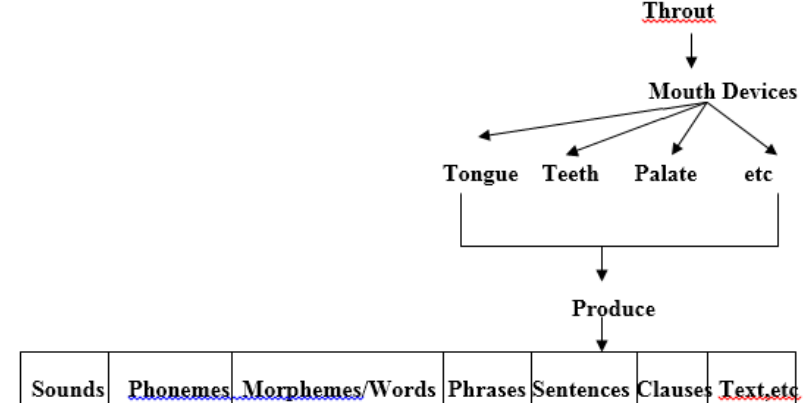

Sounds Phonemes.Morphemes/Words Phrases Sentences Clauses Text,ets

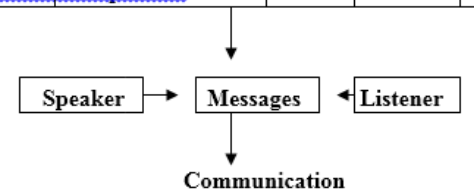

\section{Seno's Theory (5).}

\section{Diagram of Speeches Production}
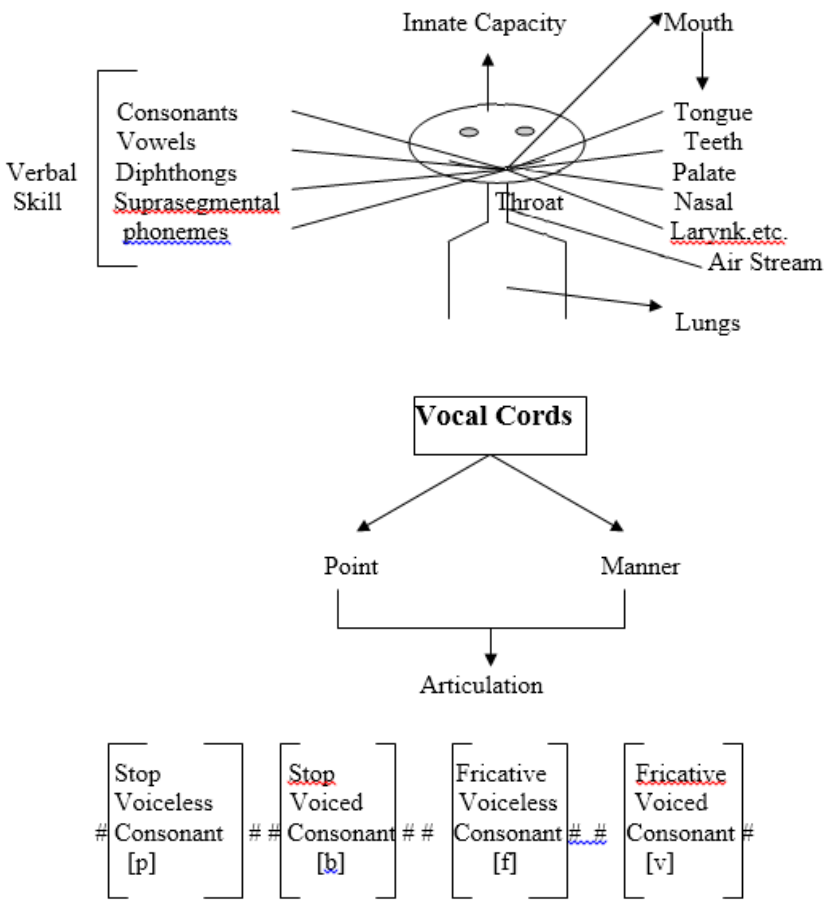

(From the above diagram, I state that Language usually is not enough in the innate capacity and talent only to produce unlimited sentences in spoken and written forms as Chomsky's and Skinner's Hypotheses, but in my mind, to produce unlimited sentences both spoken and written forms, Human also needs mentality, habits, creativity, and practice processes, including all devices of Human's body whether Verbal or Non-Verbal, and environmental effects.)

\section{Relation between Sounds and Sentenses}

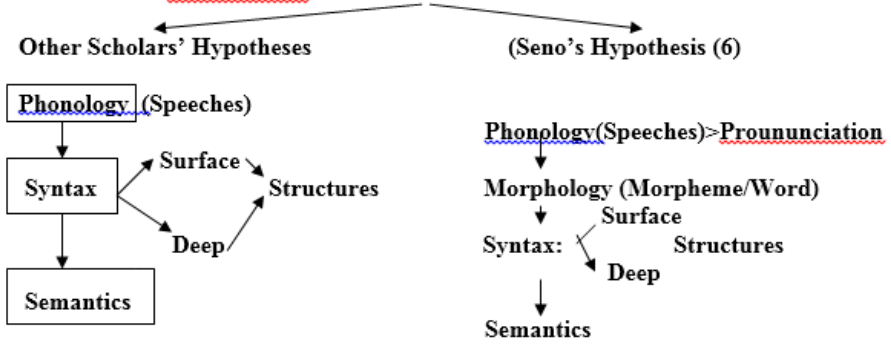

Fig.5 Human Language Process Specific and Universal.

(In my hypothesis, I add morphology after phonology, since in the processes of performing the sentences of each language in the world, we need morphemes/words before construction to be well sentences. We can not directly jump to syntax. Therefore, I ask other Scholars to think it over: Which hypothesis is accepted?). 
Sounds [p], [b], [c], [d], [f], [v], [n], [m], etcin Consonants can not stand alone, and they do not have a meaning at all. However, they must be combined with Vowels to perform morphemes/words. Example, [c] $+[\mathrm{h}]+[\mathrm{a}]+[\mathrm{i}]+[\mathrm{r}]=$ Chair. $\{$ Chair $\}$ means one morpheme and has a meaning (something used for sit). In the word of 'Chair' consists of (three consonants and two vowels). In other words, Chair has 5 letters in surface (form), and /t $\int$ ea:(r)/ has 3/4 sounds in abstractness (Deep).

\section{English Vowels Production}

\begin{tabular}{|l|l|l|}
\hline$[\mathrm{i}:]$ & & {$[\mathrm{u}:]$} \\
{$[\mathrm{I}]$} & {$[\mathrm{u}]$} \\
\hline $\begin{array}{l}{[\mathrm{e}] /[\mathrm{ei}]} \\
{[\varepsilon]}\end{array}$ & {$[\partial]$} & {$[\mathrm{o}]$} \\
\hline$[\tilde{e}]$ & {$[\mathrm{a}] /[\Lambda]$} & {$[\supset]$} \\
\hline
\end{tabular}

Book $/$ buk $/>[00] \rightarrow[0] \quad$ Man $/ \mathrm{man} />[\mathrm{a}] \rightarrow[\mathrm{a}]$

Eat $/ \mathrm{i}: \mathrm{t} />[\mathrm{ea}] \rightarrow[\mathrm{i}:]$, etc.
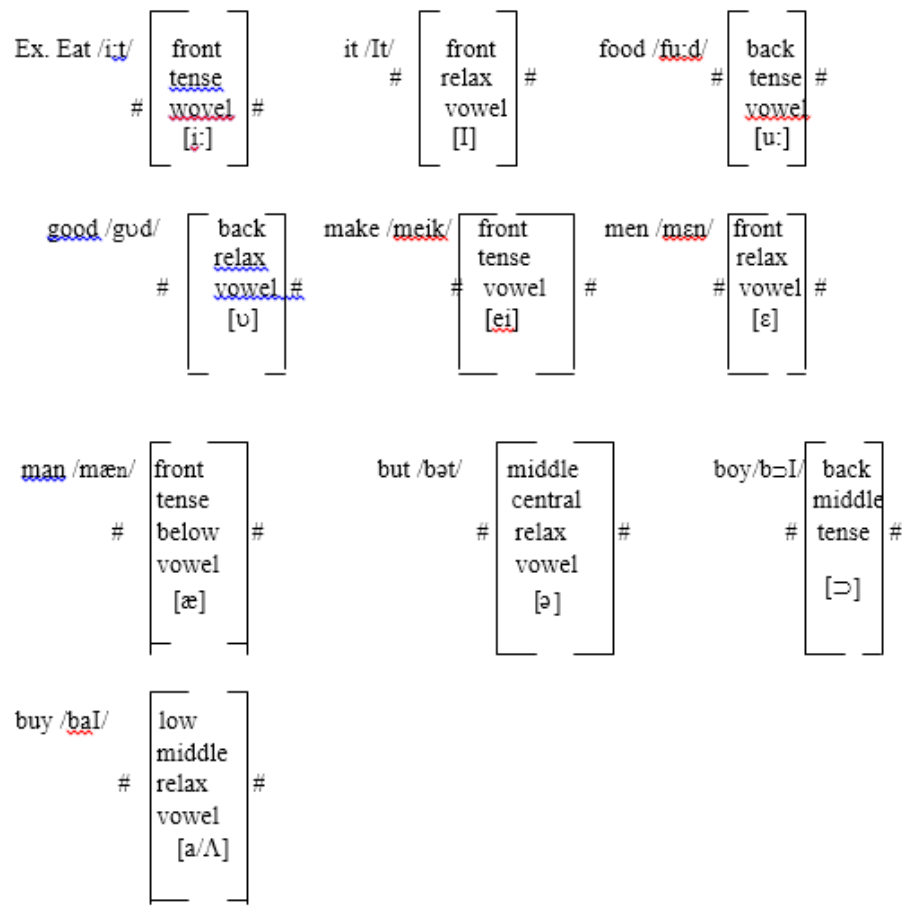

According to abstractness (deep), there are a few of sounds change based on the surface.

\section{Phonology in Research}

(Seno's Theory (7))
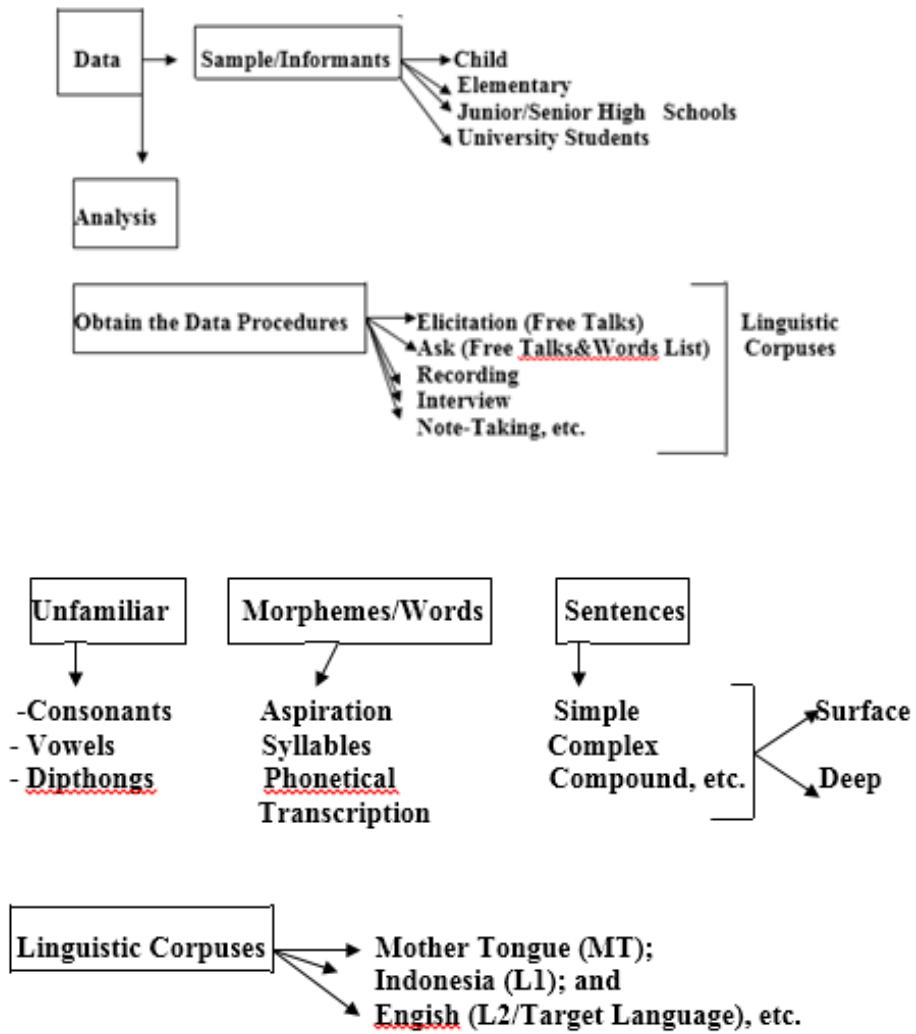

Fig.6.Data Collection Techniques of Linguistic Corpus on Phonology.

\section{Morphology}

As stated above, Morphology is a part of Linguistics studies about the formation of words derived from stem/root as seen in a tree formation. Example can be seen below.

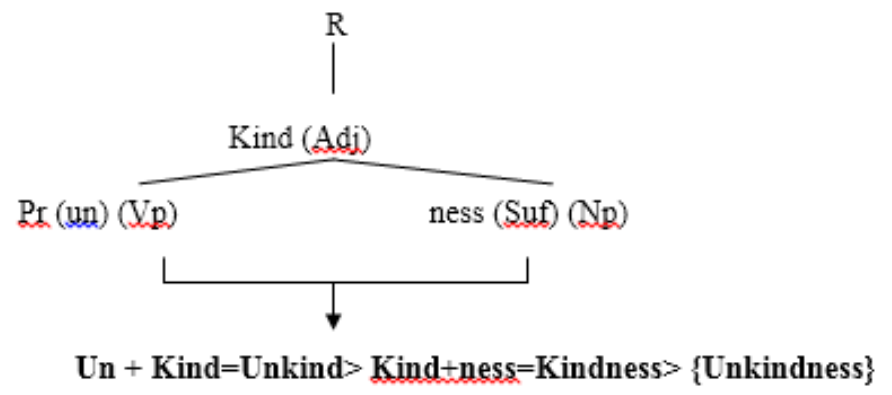

From the root of $\{$ kind $\}$ can be performed into three classes of words, such as Adjective Phrase, Verb Phrase, and Noun Phrase based on the affixation processes. The formula exists in the forms of $[\# / S u f+R=V P / \#]>[\# /+R+S u f=N P / \#]>[\# / P r+R+S u f / \#]=V P$. 


\section{Syntax}

Syntax is the science studies about the constructions of morphemes/words of Language to perform well sentences based on rules or systems of the Native Speaker. In other words, a good sentence in Syntax must be connected with rules, systems, logic, surface and deep structures. See the example of tree diagram and bracket below. Compare two Sentences below:

1. Atan Loves Ebot.

2. Ebot Loves Atan.

\section{Three Diagram}

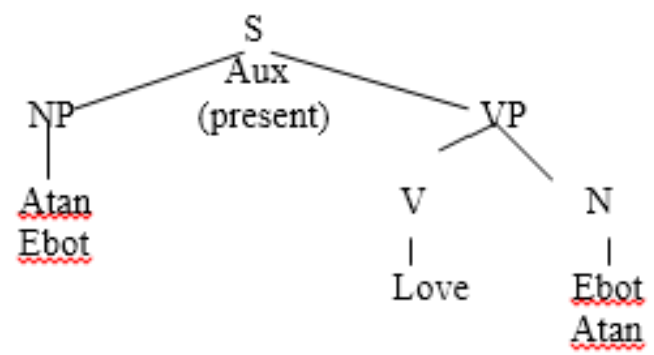

From the forms (surface), both sentences are the same structure, rules, and systems. Or in short, those sentences have (NP.1)+(VP)+(NP.2).However, according to Deep (Abstractness), semantically and logically, the sentence no.1 is more accepted by us, because according to Islam, Male proposes Female before wedding party (married Couple), not Female proposes Male. So, eventhough two sentences above have particular meanings semantically, sentence no. 1 is more logic.So, in a Language, logic is also needed to analyze words, sentences, clauses, text, etc.

\section{Other Branches or fields of Science in Linguistics}

Besides above fields of science in Linguistics, there are several branches of Linguistics must be known and learned by us, i.e., Psycholinguistics refers to behavior of Language and innate capacity of Human called "as neurological language"; Socio linguistics or Sociology of language refers to "How the people use Language in community"; Discourse Analysis refers to "What and How to analyze the spoken and written forms of Language"; Linguistics in Education modifies that "How the theory of Linguistics can be applied and educated in Teaching and Learning processes; Applied Linguistics indicates that "Every Language consists of skills as used by human in daily life, etc.

\section{Conclusion and Recommendation}

Even though Linguistics with its branches has important role is not only in Teaching Learning processes, but also it can be Science and Technology, as well as the Civilization. Therefore, Language verbally and firstly appeared in the World started from Adam Prophet, and therefore, the Language was created by the God as stated in the Alqur'an, not human, and human only develops the Languages/dialects depend on situation, condition, and civilization. Therefore, I reject other Scholars' hypotheses who involve in Linguistics and Culture in the World as they still mention that Language is a part of Culture, or created by Human.And I also reject Prof.Darwin's Hypothesis and Prof.Chaika's concepts and Hypothesis that Human is also similar to Animals (Monkey). In my analysis, The development of Languages/dialects and Cultures whether verbal skills and non-verbal skills are very different from one another. Animals from baby until adults do not have progress in using Language and Culture, even though somehow physically human looks like animal (monkey). Therefore, I hope, Linguistics can be developed by us as Scholars, since Linguistics is not only needed by Human in spoken and written forms, Teaching and Learning Processes, but it is also needed in Culture, Science and Technology,e.g., Flight, Computer, Handphone, TV Programs, Industry, etc., verbal and non-verbal.Al Qur'an is the basic of revealation of Human the World and Heaven. "God created the Languages and Colors of Human in the World, and Al Qur' an is the excellent Language in the World and Heaven, it is also a basic concept for Human life, and to develop Science and Technology in every field of Science. Lastly, I ask inside and outside Scholars to consider my hypotheses above, which hypotheses are rejected and accepted depends on every body's considerations.

\section{References}

[1] Al Qur'an Al Karim dan TerjemahnyaDepartemen Agama RI. 1996. Semarang: PT.KaryaToha Putra.

[2] S.T. Anderson. (1977). On the formal description of inflection.Proc. ChicagoLinguistic Society. 13 (15-44).

[3] Y.L. Andaya. The kingdom of johor: London: Oxford University Press, 1975.

[4] M.Aronoff. Word formation in generative grammar. Cambridge: MIT Press, 1976.

[5] R.Antilla. An introduction to historical and comparative linguistics. New York: The Macmillan Company,1972.

[6] N.Chomsky. Topics in the theory of generative grammar. Paris: Mouton,1969.

[7] N.Chomsky. Syntactic structures. Leiden: Mouton \& Co, 1975.

[8] R.Fasold. English word formation. Cambridge. Cambridge University Press, 1984.

[9] J.Lyon. Introduction to theoretical linguistics. London: Cambridge University Press, 1974.

[10] R.Lass. Phonology. Cambridge: Cambridge University Press, 1991.

[11] R. Lass. Phonology:An Introduction to Basic Concepts.NewYork:Cambridge University Press, 1991.

[12] W.P. Lehmann. Descriptive linguistics: An introduction. The University of Texas. Random House, Inc,1972.

[13] P.H. Matthews. Syntax. Cambridge: Cambridge University Press, 1992

[14] J. Miller' Semantics and syntax. Cambridge: Cambridge University Press, 1986.

[15] J. Miller. Semantics and Syntax.NewYork:Cambridge University Press, 1985.

[16] Seno,Putra. Morphology of Rengat Dialect. Pekanbaru: UIR Press, 1998 .

[17] Seno, Putra. Introduction to General Linguistics.Pekanbaru:Cedes,2000.

[18] Seno,Putra .Linguistik dan IlmuPengetahuan.Jurnal dan Orasillmiah UIR,2004.

[19] Seno,Putra. (2001).Linguistics involves in Teaching and Learning English.MakalahdanJurnalPerspektif FKIP. 
[20] Putra, Seno.1999.Analisis Wacana dalam Bahasa Media (Makalah):BulanBahasa.Pekanbaru.

[21] Putra,Seno.(2002) Dialek dan Pandangan Masyarakat MelayuterhadapBahasaMelayu. (Seminar).Selangor:UKM, Malaysia.

[22] Putra,Seno..Dialek dan Melayu Purba. Makalah.(Seminar Internasional).Auditorium UIR.Pekanbaru, 2001.

[23] Putra, Seno. Cara-cara Penulisan Karya Ilmiah Populer dan Ilmiah Akademik.Pekanbaru: UR, 2013.

[24] Putra,Seno. Syntax and Semantics.Pekanbaru: UR,2013.

[25] Putra, Seno. Maknanya Dalam Puisi. Pekanbaru: UR.,2013.

[26] Putra, Seno. The Morphology of Rengat Dialect in the Regency of Inhu, Riau Province.UIR Press dan UNRI Press,2006.

[27] Putra, Seno. Morphosyntax of TM Dialect. Pekanbaru: SusqaPresss, 2006.

[28] Putra, Seno. A Practical English Grammar Mastery.Pekanbaru:UIR Press,1992.

[29] Putra, Seno.(1998).Bahasa Melayu dan Penelitiannya (Makalah):BulanBahasa, SasanaBudaya, Pekanbaru.

[30] Putra, Seno.(2000). Beberapa Pirantidalam Sosiolinguistik. Pekanbaru:Jurnal FKIP,UIR..

[31] U. Tomori. The Morphology and Ssyntax of Present-day English. London: Heinemann,1977.

[32] T.E.Van.Applied Linguistics and the Learning and Teaching of Foreign Languages. London,NewYork:Edward Arnold, 1989.

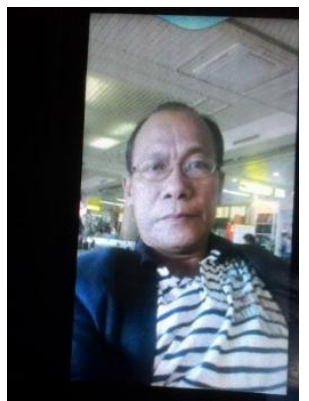

Seno H Putra, Inhu, Riau, Indonesia, August $25^{\text {th }} 1967$.

The First University Degree (Tefl), UNRI, Riau Indonesia (1991); Master Degree (Linguistics), Malang, Indonesia (1997); Ph.D Degree (Pure Linguistics), UKM, Malaysia (2004); and Professor (Pure Linguistics), (2007).

Publication for Books and Scientific Writing:

Rengat Dialect, Inhu, Riau, Indonesia (book) (1998) is the best of Scientific Research and Writing in the Board Coordinator of National Education, Sumatra Region X; Morphosyntax (Book) (2006), SusgaPress, Pekanbaru,Riau,Indonesia); Introduction to General Linguistics (Book),(UnriPress,Pekanbaru, Riau,Indonesia) (2001), etc. 